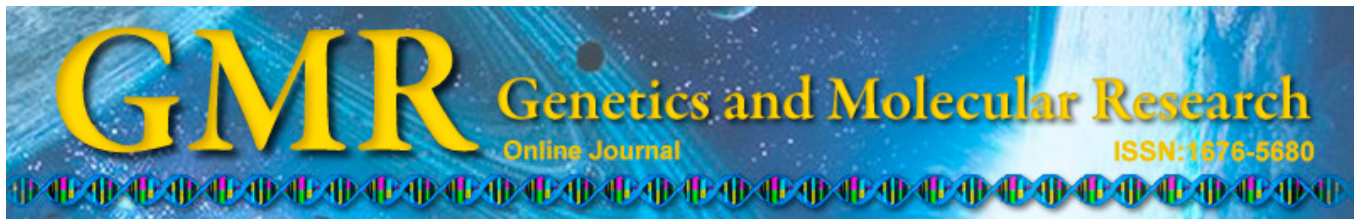

\title{
Optimization of SCoT-PCR reaction system in Dactylis glomerata by orthogonal design
}

\author{
B. Zeng ${ }^{1 *}$, X. Huang ${ }^{2 *}$, L.K. Huang ${ }^{2}$, J. Zhang ${ }^{3}$, H.D. Yan ${ }^{1}$, D. Luo ${ }^{1}$, \\ H. Liang ${ }^{1}$ and Y. Yuan ${ }^{1}$ \\ ${ }^{1}$ Department of Animal Science, Southwest University, Rongchang, \\ Chongqing Province, China \\ ${ }^{2}$ Department of Grassland Science, \\ College of Animal Science and Technology College, \\ Sichuan Agricultural University, Ya'an, Sichuan Province, China \\ ${ }^{3}$ Chongqing Academy of Animal Sciences, Yuzhong, Chongqing Province, China \\ *These authors contributed equally to this study. \\ Corresponding authors: L.K. Huang / J. Zhang \\ E-mail: huanglinkai@sicau.edu.cn / zjturf@163.com
}

Genet. Mol. Res. 14 (2): 3052-3061 (2015)

Received May 11, 2014

Accepted October 21, 2014

Published April 10, 2015

DOI http://dx.doi.org/10.4238/2015.April.10.15

ABSTRACT. The effects of 5 factors (template DNA, $\mathrm{Mg}^{2+}$, dNTPs,
Taq DNA polymerase, and primer) on the polymerase chain reaction
(PCR) were investigated to optimize the start codon targeted polymor-
phism (SCoT)-PCR system of Dactylis glomerata $\mathrm{L}$., using an orthogo-
nal design $\mathrm{L}_{16}\left(4^{5}\right)$. A suitable SCoT-PCR system for $D$. glomerata was
established; the $20 \mu \mathrm{L}$ reaction volume contained $3.0 \mathrm{mM} \mathrm{Mg}^{2+}, 0.2$
$\mathrm{mM}$ dNTPs, $1.0 \mathrm{U}$ Taq DNA polymerase, $0.2 \mu \mathrm{M}$ primer, $20 \mathrm{ng}$ tem-
plate DNA, and $2 \mu \mathrm{L} 10 \mathrm{X}$ buffer. Each factor had a different effect on
the amplification reaction, and the concentration of dNTPs had the larg-
est effect on the SCoT-PCR system. We tested 10 orchardgrass samples
to determine and verify the stability of the reaction system. The results
showed that amplified bands from diverse materials were clear, stable, 
and rich in polymorphisms, indicating that the optimized system was very stable.

Key words: Dactylis glomerata L.; Reaction system; Optimization; Start codon target polymorphism-polymerase chain reaction; Orchardgrass; Orthogonal design

\section{INTRODUCTION}

Orchardgrass, or cocksfoot (Dactylis glomerata L.), is a common species of Poaceae in the genus Dactylis and is one of the most important cool-season perennial $\mathrm{C}_{3}$ bunchgrasses. This plant is commonly used for forage and hay production worldwide because of its remarkable local adaptation, good tolerance to shadow (and thus is also known as orchardgrass), high yield, and high sugar content (Horn et al., 1988; Bushman et al., 2011; Xie et al., 2012). It plays an important role as forage material in North America, Europe (Casler et al., 2000), and Oceania, as well as in grassland animal husbandry and ecological construction of southern subtropical mountains of China. Because of the importance of orchardgrass as a forage and hay grass, in recent years, a number of studies have been performed to examine orchardgrass morphology (Felfoldi, 1975; Turner et al., 2012), anatomy (Ashenden, 1978), cytology (Lentz et al., 1983; Tosun et al., 1999), physiology (Davidson and Milthorpe, 1966; Yoshida and Uemura, 1984; Volaire, 1995; Volaire and Lelièvre, 2001), ecology (Eagles, 1983; Fan, 1997; Kyriazopoulos et al., 2013), and breeding (Denchev et al., 1997; Casler et al., 2000; Hopkins and Bhamidimarri, 2009). Molecular-level studies of orchardgrass have also been conducted. Numerous types of molecular genetic marker systems have been developed for use in germplasm resources studies of orchardgrass, including amplified fragment length polymorphism markers (Reeves et al., 1998; Peng et al., 2008), random amplified polymorphic DNA markers (Kölliker et al., 1999; Tuna et al., 2004), sequence-related amplified polymorphism markers (Zeng et al., 2008; Scoles et al., 2010), inter-simple sequence repeat markers (Zeng et al., 2006), simple sequence repeat (SSR) markers (Xie et al., 2010, 2012; Song et al., 2011; Last et al., 2013), and expressed sequence tag-SSR markers (Bushman et al., 2011). These studies have revealed varying levels of molecular genetic diversity depending on the type of molecular marker and the population examined (Mulpuri et al., 2013). However, start codon targeted (SCoT) polymorphism has not been applied in orchardgrass.

The start codon targeted (SCoT) polymorphism is simple, novel, and reliable method for generating gene-targeted markers developed by Collard and Mackill (2009) and validated in rice (Oryza sativa). It uses 18-mer single primers with polymerase chain reaction (PCR); the primers are simple to design and used to amplify the genomic region based on conservation of the ATG translation start site and flanking sequences in plant genes (Joshi et al., 1997; Collard and Mackill, 2009). SCoT is similar to random amplified polymorphic DNA or intersimple sequence repeat, but has some advantages such as being closely linked with the target gene, provides more information correlated with biological traits, and universality in plants compared with random DNA markers. These advantages have been verified in rice (Oryza sativa) (Collard and Mackill, 2009), mango (Mangifera indica) (Luo et al., 2011), peanut (Arachis hypogaea) (Xiong et al., 2011), grape (Vitis vinifera) (Guo et al., 2012), dendrobe (Dendrobium nobile) (Bhattacharyya et al., 2013), and limpograss (Hemarthria altissima) (Huang et al., 2013) for cultivar identification and genetic diversity analysis. 
Despite the advantages of the SCoT method, there are also limitations, such as the lack of polymorphisms detected because of the low stringency PCR conditions. SCoT relies on PCR-based methods, and the stability of the PCR is affected by numerous factors, including $\mathrm{Mg}^{2+}$, dNTPs, primer, and Taq DNA polymerase concentrations, and diverse species required different PCR conditions. Hence, it is important to establish a stable and optimized reaction system for use with SCoT molecular markers. PCR reaction conditions are traditionally optimized using the one-factor-at-a-time method, neglecting the interactions between the various factors. We employed an orthogonal design referred to as $\mathrm{L}_{16}\left(4^{5}\right)$ (4 levels of 5 factors: Taq DNA polymerase, $\mathrm{Mg}^{2+}$, DNA template, dNTPs, and primer) to optimize the SCoTPCR system for orchardgrass and to provide a method for studying genetic diversity, genetic relationships, the construction of molecular linkage genetic maps, variety identification, gene localization, quantitative trait loci analysis, and molecular marker-assisted breeding in orchardgrass.

\section{MATERIAL AND METHODS}

\section{Tested materials}

The materials used in this study were collected from the Teaching and Research Center at Southwest University (Rongchang), Chongqing in China in May 2013 (Table 1). Fresh young leaves were sampled directly from soil, placed in a refrigerator, and stored at $-80^{\circ} \mathrm{C}$. The sequence of the SCoT primer was as described by Luo et al. (2011), SCoT 1: 5'-CAACAATGGCTACCACGC-3' and SCoT 2: 5'-ACAATGGCTACCACTGCC-3', and were synthesized by Shanghai Shenggong Biological Engineering Technology Services Ltd. (Shanghai, China). $\mathrm{Mg}^{2+}$, dNTPs, Taq DNA polymerase, 10X buffer, 6X buffer, and DL2000 marker were purchased from Takara Biotechnology (Dalian) Co., Ltd. (Shiga, Japan).

\begin{tabular}{lll}
\multicolumn{2}{|c}{ Table 1. Names and types of orchardgrass samples used in this study. } \\
\hline No. & Material name & Type \\
\hline 1 & Bao Xin & Cultivar \\
2 & Parthlong & Wild Material \\
3 & PG337 & Wild Material \\
4 & $90-130$ & Wild Material \\
5 & Smithii & Cultivar \\
6 & Bueno chile & Wild Material \\
7 & Judiaca & Wild Material \\
8 & General Belgrano & Cultivar \\
9 & PG318 & Wild Material \\
10 & Crown & Cultivar \\
11 & Porto & Cultivar \\
12 & Akimidori Japan & Cultivar \\
13 & PG76xPorto & Hybrid Material \\
\hline
\end{tabular}

\section{DNA extraction and SCoT-PCR program}

DNA was extracted from fresh young leaf samples using a genomic DNA extraction kit (ComWin Biotechnology Co., Ltd., Beijing, China) following the manufacturer protocol. The quality and concentration of genomic DNA were determined using $1 \%(\mathrm{wt} / \mathrm{vol})$ agarose gel electrophoresis and spectrophotometric analysis with the NanoDrop 2000 nucleic acid/ 
protein analyzer (Nanodrop Technologies, Wilmington, DE, USA). Isolated genomic DNA was diluted to $20 \mathrm{ng} / \mathrm{mL}$ and stored at $-20^{\circ} \mathrm{C}$.

PCR amplification reaction was performed in an Eppendorf Mastercycler (Hamburg, Germany) using the following program: 3 min at $94^{\circ} \mathrm{C}$, followed by 36 cycles of denaturing at $94^{\circ} \mathrm{C}$ for $30 \mathrm{~s}$, annealing at $50^{\circ} \mathrm{C}$ for $1 \mathrm{~min}$, extension at $72^{\circ} \mathrm{C}$ for $2 \mathrm{~min}$, followed by a final extension at $72^{\circ} \mathrm{C}$ for $10 \mathrm{~min}$ and storage at $4^{\circ} \mathrm{C}$. After amplification, $2 \mu \mathrm{L} 6 \mathrm{X}$ buffer was added to the PCR amplification products. Next, $8-10 \mu \mathrm{L}$ PCR products for each treatment were separated on $1.5 \%$ agarose gels in $1 \mathrm{X}$ Tris-borate EDTA buffer and stained with GoldView ${ }^{\mathrm{TM}}$ dye (Beijing Bioteke Biotechnology Co., Beijing, China). DNA fragments were visualized under UV light and photographed using a gel documentation system (Bio-Rad, Hercules, CA, USA).

\section{Orthogonal optimization design of SCoT-PCR system}

We examined the optimum concentrations of template DNA (Bao Xin), $\mathrm{Mg}^{2+}$, dNTPs, Taq DNA polymerase, and primer (SCoT 1: 5'- CAACAATGGCTACCACGC-3') using an orthogonal design $\mathrm{L}_{16}\left(4^{5}\right)$. The 4 concentrations for each of the 5 factors were chosen based on references and experience, and the levels and detailed experimental concentrations for each factor are listed in Table 2. The $\mathrm{L}_{16}\left(4^{5}\right)$ orthogonal experimental design is shown in Table 3 . Amplification conditions were as follows: total volume of $20 \mu \mathrm{L}, 2.0 \mu \mathrm{L} 10 \mathrm{X}$ buffer and other components, and $\mathrm{ddH}_{2} \mathrm{O}$ to reach the total volume.

Table 2. Factors and volume levels of SCoT-PCR amplification for Dactylis glomerata.

\begin{tabular}{lccccc}
\hline Levels & \multicolumn{5}{c}{ Factors } \\
\cline { 2 - 6 } & $\mathrm{Mg}^{2+}(\mathrm{mM})$ & $\mathrm{dNTPs}(\mathrm{mM})$ & Taq DNA polymerase $(\mathrm{U})$ & Primers $(\mu \mathrm{M})$ & Template DNA (ng) \\
\hline 1 & 1.5 & 0.15 & 0.75 & 0.2 & 20 \\
2 & 2.0 & 0.20 & 1.00 & 0.3 & 30 \\
3 & 2.5 & 0.25 & 1.25 & 0.4 & 40 \\
4 & 3.0 & 0.30 & 1.50 & 0.5 & 50 \\
\hline
\end{tabular}

Table 3. $\mathrm{L}_{16}\left(4^{5}\right)$ orthogonal design of SCoT-PCR amplification for Dactylis glomerata.

\begin{tabular}{|c|c|c|c|c|c|c|}
\hline Treatment No. & $\mathrm{Mg}^{2+}(\mathrm{mM})$ & dNTPs (mM) & Taq DNA polymerase (U) & Primers $(\mu \mathrm{M})$ & Template DNA (ng) & Score \\
\hline 1 & $1.5(1)$ & $0.15(1)$ & $0.75(1)$ & $0.2(1)$ & $20(1)$ & 11 \\
\hline 2 & $1.5(1)$ & $0.20(2)$ & $1.00(2)$ & $0.3(2)$ & $30(2)$ & 9 \\
\hline 3 & $1.5(1)$ & $0.25(3)$ & $1.25(3)$ & $0.4(3)$ & $40(3)$ & 14 \\
\hline 4 & $1.5(1)$ & $0.30(4)$ & $1.50(4)$ & $0.5(4)$ & $50(4)$ & 3 \\
\hline 5 & $2.0(2)$ & $0.15(1)$ & $1.00(2)$ & $0.4(3)$ & $50(4)$ & 6 \\
\hline 6 & $2.0(2)$ & $0.20(2)$ & $0.75(1)$ & $0.5(4)$ & $40(3)$ & 12 \\
\hline 7 & $2.0(2)$ & $0.25(3)$ & $1.50(4)$ & $0.2(1)$ & $30(2)$ & 10 \\
\hline 8 & $2.0(2)$ & $0.30(4)$ & $1.25(3)$ & $0.3(2)$ & $20(1)$ & 1 \\
\hline 9 & $2.5(3)$ & $0.15(1)$ & $1.25(3)$ & $0.5(4)$ & $30(2)$ & 7 \\
\hline 10 & $2.5(3)$ & $0.20(2)$ & $1.50(4)$ & $0.4(3)$ & $20(1)$ & 13 \\
\hline 11 & $2.5(3)$ & $0.25(3)$ & $0.75(1)$ & $0.3(2)$ & $50(4)$ & 4 \\
\hline 12 & $2.5(3)$ & $0.30(4)$ & $1.00(2)$ & $0.2(1)$ & $40(3)$ & 8 \\
\hline 13 & $3.0(4)$ & 0.15 (1) & $1.50(4)$ & $0.3(2)$ & $40(3)$ & 5 \\
\hline 14 & $3.0(4)$ & $0.20(2)$ & $1.25(3)$ & $0.2(1)$ & $50(4)$ & 15 \\
\hline 15 & $3.0(4)$ & $0.25(3)$ & $1.00(2)$ & $0.5(4)$ & $20(1)$ & 16 \\
\hline 16 & $3.0(4)$ & 0.30 (4) & 0.75 (1) & $0.4(3)$ & $30(2)$ & 2 \\
\hline
\end{tabular}




\section{Stability of optimal reaction system}

We used the DNA samples to examine the stability of the highest scored orthogonal experiment treatment and the statistical optimal treatment. We also selected the best treatment to verify the stability of the reaction system using the primer SCoT 2 and 10 orchardgrass samples.

\section{RESULTS}

\section{Visual analysis of PCR orthogonal design}

The PCR amplification products of the orthogonal experiment treatments showed variable fingerprinting patterns, treatment 8 showed no fragments, and treatment 15 showed the largest number of fragments (Figure 1). A scoring system was applied to determine variance between the SCoT-PCR fingerprint patterns using different treatments. According to $\mathrm{He}$ et al. (1998), DNA amplification patterns generated were scored on the scale of the best (16 points) to worst (1 point) using scoring criteria, including amplified fragment number and clear degree of PCR amplification results (Table 3). According to the score for each treatment, the experimental value $\mathrm{K}_{\mathrm{i}}$ of the score for each factor at the same level, the experimental value ki of mean of score in each factor under levels, and the range $\mathrm{R}$ of the mean of score for the same factors between different levels are shown in Table 4 .

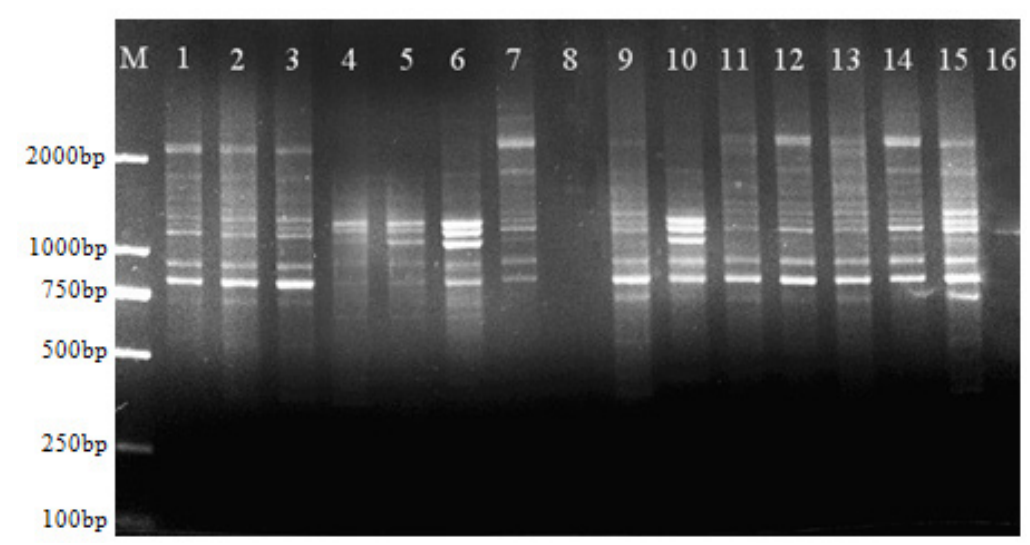

Figure 1. Electrophoresis using orthogonal design to obtain PCR products. Lane $M$ = DNA marker DL2000; lanes 1-16: Treatment numbers are same as those in Table 1.

Table 4. Analysis of orthogonal design.

\begin{tabular}{lccccc}
\hline Results & $\mathrm{Mg}^{2+}(\mathrm{mM})$ & dNTPs $(\mathrm{mM})$ & Taq DNA polymerase $(\mathrm{U})$ & Primers $(\mu \mathrm{M})$ & Template DNA $(\mathrm{ng})$ \\
\hline $\mathrm{K}_{1}$ & 37.00 & 29.00 & 29.00 & 44.00 & 41.00 \\
$\mathrm{~K}_{2}$ & 29.00 & 49.00 & 39.00 & 19.00 & 28.00 \\
$\mathrm{~K}_{3}$ & 32.00 & 44.00 & 37.00 & 35.00 & 39.00 \\
$\mathrm{~K}_{4}$ & 38.00 & 14.00 & 31.00 & 38.00 & 28.00 \\
$\mathrm{k} 1$ & 9.25 & 12.25 & 7.25 & 4.75 & 7.00 \\
$\mathrm{k} 2$ & 7.25 & 11.00 & 9.75 & 9.75 & 7.00 \\
$\mathrm{k} 3$ & 8.00 & 3.50 & 9.25 & 7.75 \\
$\mathrm{k} 4$ & 9.50 & 8.75 & 7.75 & 6.25 & 7.00 \\
$\mathrm{R}$ & 2.25 & & 2.50 & & 3.25 \\
\hline
\end{tabular}


Range $\mathrm{R}$ reflects the influence template DNA, $\mathrm{Mg}^{2+}$, dNTPs, Taq DNA polymerase, and primer concentrations on the reaction system. A larger range for $\mathrm{R}$ indicated a more significant influence of the factor. We found that the factors affected fingerprinting patterns in the order of dNTPs, primers, template DNA, Taq DNA polymerase, and $\mathrm{Mg}^{2+}$, from largest to smallest effect.

The values ki reflects the influence of each factor under each level on the reaction system; a larger ki value indicates a better reaction level. The ki value can indicate the optimal concentration of each factor. By transforming the ki value of mean of score in each factor under levels into line charts, the relationship between the 5 factors and the mean of result of

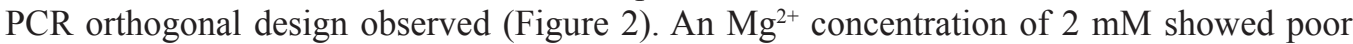
performance in the amplification reaction, while other tested $\mathrm{Mg}^{2+}$ concentrations showed good amplification results; the best performance was observed at $3.0 \mathrm{mM} \mathrm{Mg}^{2+}$ (Figure 2A).
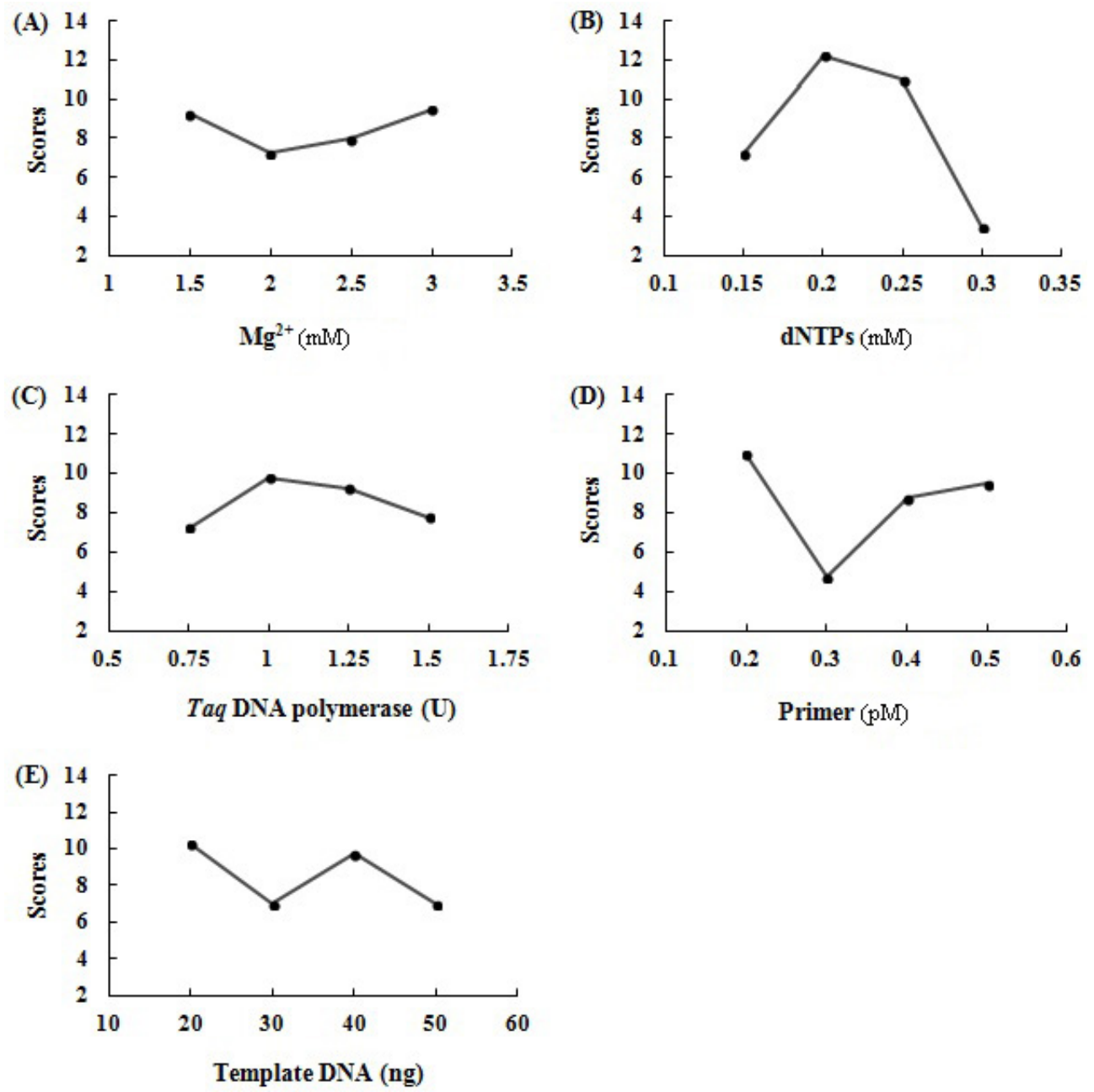

Figure 2. Relationship between 5 factors of (A) $\mathrm{Mg}^{2+}$, (B) dNTPs, (C) Taq DNA polymerase, (D) Primer, (E) Template DNA, as well as the mean of score of PCR orthogonal design. 
dNTPs are the substrates of Taq DNA polymerase, and their concentrations directly affect the results of the PCR. In the study, changes in dNTP concentration had a large impact on the orchardgrass SCoT-PCR reaction. With increasing dNTP concentration, the mean of result of PCR orthogonal design increased and then decreased. A dNTP concentration of $0.2 \mathrm{mM}$ was associated with the best amplification results (Figure 2B). Taq DNA polymerase is a key factor in the PCR. The fingerprint patterns showed large differences at varying Taq DNA polymerase concentrations of $0.75-1.5 \mathrm{U}$, and the best fingerprint patterns were obtained at $1.0 \mathrm{U}$ Taq polymerase (Figure 2C). Primer concentration also plays an important role in fingerprinting band patterns, and high primer concentration can increase the formation of primer dimers. Hence, the concentration with the highest score, $0.2 \mu \mathrm{M}$, should be used (Figure 2D). Appropriate DNA concentration is a prerequisite for amplification; high DNA concentration will increase nonspecific amplification products. As shown in Figure 2E, template DNA concentrations of 20 and $40 \mathrm{ng}$ showed good performance in the amplification reaction, and the best performance was observed at a concentration of $20 \mathrm{ng}$.

Based on our results, we found that the most suitable concentration of the 5 factors in this study were as follows: $3.0 \mathrm{mM} \mathrm{Mg}^{2+}, 0.2 \mathrm{mM}$ dNTPs, $1.0 \mathrm{U}$ Taq DNA polymerase, $0.2 \mu \mathrm{M}$ primer, and $20 \mathrm{ng}$ template DNA. These concentrations showed some differences in amplification efficiency compared to the highest scored treatment $\left(3.0 \mathrm{mM} \mathrm{Mg}{ }^{2+}, 0.25 \mathrm{mM}\right.$ dNTPs, $1 \mathrm{U}$ Taq DNA polymerase, $0.5 \mu \mathrm{M}$ primer, and $20 \mathrm{ng}$ template DNA). To verify the efficiency of the conditions showing the highest score, different template DNA was amplified. As shown in Figure 2, the amplification results of the 2 systems were good, and the fingerprinting patterns were very similar, but the amplified fragments for the statistically optimal treatment were brighter than those for the highest scored treatment (Figure 3). Therefore, the most suitable SCoT-PCR reaction system was $20 \mu \mathrm{L}$ and contained $3.0 \mathrm{mM} \mathrm{Mg}^{2+}, 0.2 \mathrm{mM}$ dNTPs, $1.0 \mathrm{U}$ Taq DNA polymerase, $0.2 \mu \mathrm{M}$ primer, $20 \mathrm{ng}$ template DNA, and $2 \mu \mathrm{L} 10 \mathrm{X}$ buffer.

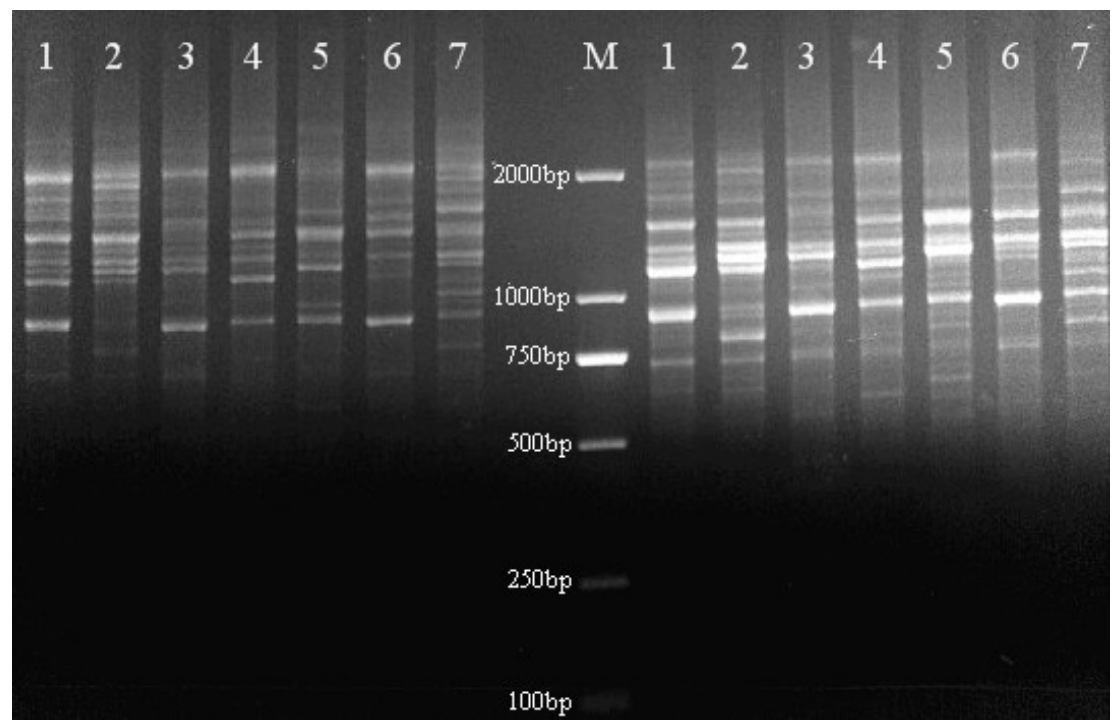

Figure 3. Electrophoresis of the statistical optimal reaction system (right) and the highest scored orthogonal reaction system (left). Lane M: DNA marker DL2000; lanes 1-7: Parthlong, PG337, Bueno Chile, PG318, Porto, Akimidori Japan, PG76 x Porto. 


\section{Stability of the optimized reaction system}

The primer SCoT 2 and 10 orchardgrass samples were used to verify the stability of the optimal reaction system. Figure 4 shows that the amplification bands of diverse samples were clear, stable, and rich in polymorphisms. The fingerprinting patterns of the 10 orchardgrass samples not only reflected the genetic stability of each sample, but also revealed the genetic differences between samples, indicating that the optimized reaction system can be applied for SCoT-PCR analysis of orchardgrass.

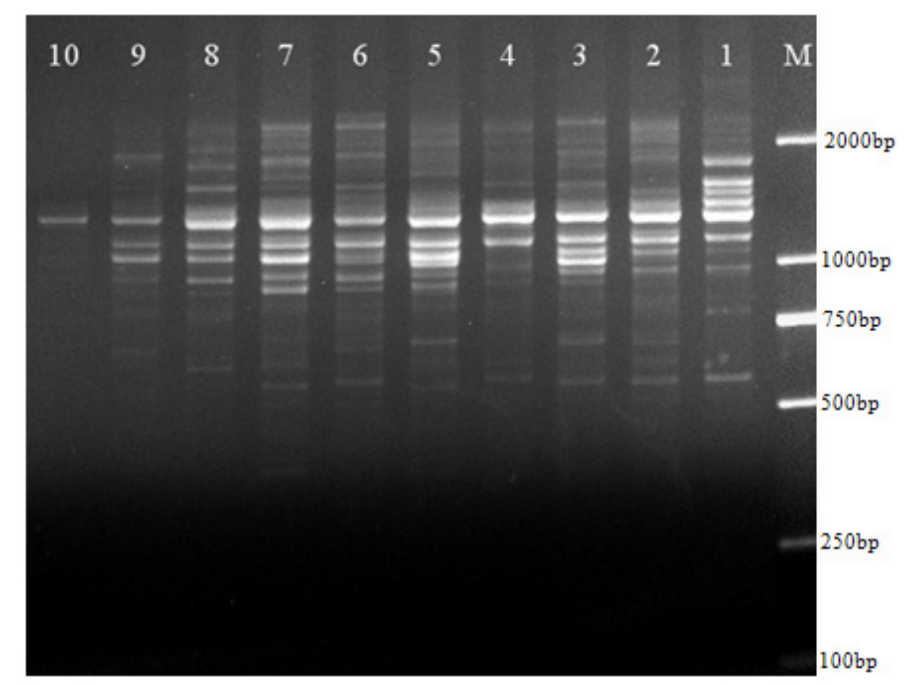

Figure 4. Electrophoresis of materials of orchardgrass using the optimized reaction system. Lane M: DNA marker DL2000; lanes 1-10: 90-130, Smithii, Bueno Chile, Judiaca, General Belgrano, PG318, Crown, Porto, Akimidori Japan, PG76 x Porto.

\section{DISCUSSION}

Variations in the 5 factors tested changed the fingerprinting patterns significantly, and dNTP concentration was considered to be the most important factor affecting the PCR, which is consistent with the results obtained by Wang et al. (2007). Low dNTP concentration produce relatively poor amplification fingerprints, while high concentration compete with Taq DNA polymerase for $\mathrm{Mg}^{2+}$, reducing $\mathrm{Mg}^{2+}$ concentration and the activity of Taq DNA polymerase, eventually leading to the low PCR amplification levels. Therefore, the most effective dNTP concentration was a median of $0.2 \mathrm{mM}$. $\mathrm{Mg}^{2+}$ concentration had a minimal impact on the PCR results in our study. However, this result was in contrast to those of Xie et al. (2008) who used SSR markers analysis. This may be because $\mathrm{Mg}^{2+}$ concentration was influenced by the interaction of various factors ( Taq DNA polymerase, dNTPs, etc.) in the PCR system, thus showing varying levels of performance; this may be associated with the orthogonal design and the use of subjective scoring.

It is important to optimize the SCoT-PCR system for orchardgrass. Using an orthogonal design $\mathrm{L}_{16}\left(4^{5}\right)$ to optimize the SCoT-PCR system in this study, we developed a rapid and simple method for investigating the mutual effects of factors and obtain satisfactory results. 
Our SCoT-PCR system can be used for follow-up studies to further optimize the SCoT-PCR conditions in orchardgrass, particularly for genetic diversity analysis and molecular markerassisted breeding of orchardgrass using SCoT.

\section{ACKNOWLEDGMENTS}

Research supported by the National Natural Science Foundation of China (NSFC) (\#31101760; \#31201845), Fundamental Research Funds for the Central Universities of China (\#XDJK2013C140), and the Funding Project of 2013 Chongqing Universities Innovation Team Building Plan "Modern Technology in Beef Cattle Production".

\section{REFERENCES}

Ashenden TW (1978). Drought avoidance in sand dune populations of Dactylis glomerata. J. Ecol. 66: 943-951.

Bhattacharyya P, Kumaria S, Kumar S and Tandon P (2013). Start Codon Targeted (SCoT) marker reveals genetic diversity of Dendrobium nobile Lindl., an endangered medicinal orchid species. Gene 529: 21-26.

Bushman BS, Larson SR, Tuna M, West MS, et al. (2011). Orchardgrass (Dactylis glomerata L.) EST and SSR marker development, annotation, and transferability. Theor. Appl. Genet. 123: 119-129.

Casler MD, Fales SL, McElroy AR, Hall MH, et al. (2000). Genetic progress from 40 years of orchardgrass breeding in North America measured under hay management. Crop Sci. 40: 1019-1025.

Collard BC and Mackill DJ (2009). Start codon targeted (SCoT) polymorphism: a simple, novel DNA marker technique for generating gene-targeted markers in plants. Plant Mol. Biol. Rep. 27: 86-93.

Davidson JL and Milthorpe FL (1966). The effect of defoliation on the carbon balance in Dactylis glomerata. Ann. Bot. 30: $185-198$.

Denchev PD, Songstad DD, McDaniel JK, and Conger BV (1997). Transgenic orchardgrass (Dactylis glomerata) plants by direct embryogenesis from microprojectile bombarded leaf cells. Plant Cell Rep. 16: 813-819.

Eagles CF (1983). Relationship between competitive ability and yielding ability in mixtures and monocultures of populations of Dactylis glomerata L. Grass Forage Sci. 38: 21-24.

Fan JW (1997). A study on competition between orchardgrass and ryegrass in mixed pasture under different management conditions. Acta Pratacul. Sin. 6: 23-31.

Felfoldi EM (1975). Classification of Dactylis glomerata florets based on caryopsis size. Seed Sci. Technol. 3: 499-502.

Guo DL, Zhang JY and Liu CH (2012). Genetic diversity in some grape varieties revealed by SCoT analyses. Mol. Biol. Rep. 39: 5307-5313.

He ZW, Liu YS, Chen LH, Cao MH, et al. (1998). Orthogonal design-direct analysis for PCR optimization. Hunan Yi Ke Da Xue Bao 23: 403-404.

Hopkins AA, and Bhamidimarri S (2009). Breeding summer-dormant grasses for the United States. Crop Sci. 49: 2359 2362.

Horn ME, Shillito RD, Conger BV and Harms CT (1988). Transgenic plants of Orchardgrass (Dactylis glomerata L.) from protoplasts. Plant Cell Rep. 7: 469-472.

Huang X, Zhang XQ, Zhang Y, Jiang XM, et al. (2013). Genetic diversity of Hemarthria altissima and its relative species by SCoT markers. Chinese J. Trop. Crops. 34: 2192-2199.

Joshi CP, Zhou H, Huang X and Chiang VL (1997). Context sequences of translation initiation codon in plants. Plant Mol. Biol. 35: 993-1001.

Kölliker R, Stadelmann FJ, Reidy B and Nösberger J (1999). Genetic variability of forage grass cultivars: A comparison of Festuca pratensis Huds., Lolium perenne L., and Dactylis glomerata L. Euphytica 106: 261-270.

Kyriazopoulos AP, Abraham EM, Parissi ZM, Koukoura Z, et al. (2013). Forage production and nutritive value of Dactylis glomerata and Trifolium subterraneum mixtures under different shading treatments. Grass Forage Sci. 68: 72-82.

Last L, Widmer F, Fjellstad W, Stoyanova S, et al. (2013). Genetic diversity of natural orchardgrass (Dactylis glomerata L.) populations in three regions in Europe. BMC Genet. 14: 102.

Lentz EM, Crane CF, Sleper DA and Loegering WQ (1983). An assessment of preferential chromosome pairing at meiosis in Dactylis glomerata. Can. J. Genet. Cytol. 25: 222-232.

Luo C, He XH, Chen $\mathrm{H}, \mathrm{Ou} \mathrm{Sj}$, et al. (2011). Genetic diversity of mango cultivars estimated using SCoT and ISSR markers. Biochem. Syst. Ecol. 39: 676-684. 
Mulpuri S, Muddanuru T and Francis G (2013). Start codon targeted (SCoT) polymorphism in toxic and non-toxic accessions of Jatropha curcas L. and development of a codominant SCAR marker. Plant Sci. 207: 117-127.

Peng Y, Zhang XQ, Deng YL and Ma X (2008). Evaluation of genetic diversity in wild orchardgrass (Dactylis glomerata L.) based on AFLP markers. Hereditas 145: 174-181.

Reeves G, Francis D, Davies MS, Rogers HJ, et al. (1998). Genome size is negatively correlated with altitude in natural populations of Dactylis glomerata. Ann. Bot. 82: 99-105.

Scoles G, Xie W, Zhang X, Cai H, et al. (2010). Genetic maps of SSR and SRAP markers in diploid orchardgrass (Dactylis glomerata L.) using the pseudo-testcross strategy. Genome 54: 212-221.

Song YH, Liu FX, Zhu ZF, Tan LB, et al. (2011). Construction of a simple sequence repeat marker-based genetic linkage map in the autotetraploid forage grass Dactylis glomerata L. Grassland Sci. 57: 158-167.

Tosun M, Akguen J and Sagsoez S (1999). Determination of some cytological characters of wild orchardgrass (Dactylis glomerata L.) growing in Erzurum district. Turk. J. Agric. For. 23: 219-228.

Tuna M, Khadka DK, Shrestha MK, Arumuganathan K, et al. (2004). Characterization of natural orchardgrass (Dactylis glomerata L.) populations of the Thrace Region of Turkey based on ploidy and DNA polymorphisms. Euphytica 135: 39-46.

Turner LR, Holloway-Phillips MM, Rawnsley RP, Donaghy DJ, et al. (2012). The morphological and physiological responses of perennial ryegrass (Lolium perenne L.), cocksfoot (Dactylis glomerata L.) and tall fescue (Festuca arundinacea Schreb.; syn. Schedonorus phoenix Scop.) to variable water availability. Grass Forage Sci. 67: 507-518.

Volaire F (1995). Growth, carbohydrate reserves and drought survival strategies of contrasting Dactylis glomerata populations in a Mediterranean environment. J. Appl. Ecol. 32: 56-66.

Volaire F and Lelièvre F (2001). Drought survival in Dactylis glomerata and Festuca arundinacea under similar rooting conditions in tubes. Plant Soil 229: 225-234.

Wang ZG, Zhang HY, Yu GJ, Zhang F, et al. (2007). The orthogonal optimization of SRAP amplification system in Cucumber. Acta Agr. Boreali-Sin. 22: 112-115.

Xie WG, Zhang XQ, Ma X, Cai HW, et al. (2010). Diversity comparison and phylogenetic relationships of cocksfoot (Dactylis glomerata L.) germplasm as revealed by SSR markers. Can. J. Plant Sci. 90: 13-21.

Xie WG, Zhang XQ, Peng Y, Ma X, et al. (2008). Optimization of SSR-PCR reaction system in Dactylis glomerata and SSR primer selection. Mol. Plant Breed. 6: 381-386.

Xie WG, Robins JG, Bushman BS and Gustafson J (2012). A genetic linkage map of tetraploid orchardgrass (Dactylis glomerata L.) and quantitative trait loci for heading date. Genome 55: 360-369.

Xiong FQ, Zhong RC, Han ZQ, Jiang J, et al. (2011). Start codon targeted polymorphism for evaluation of functional genetic variation and relationships in cultivated peanut (Arachis hypogaea L.) genotypes. Mol. Biol. Rep. 38: 3487 3494.

Yoshida S and Uemura M (1984). Protein and lipid compositions of isolated plasma membranes from orchard grass (Dactylis glomerata L.) and changes during cold acclimation. Plant Physiol. 75: 31-37.

Zeng B, Zhang XQ, Fan Y, Lan Y, et al. (2006). Genetic diversity of Dactylis glomerata germplasm resources detected by inter-simple sequence repeats (ISSRs) molecular markers. Yi Chuan 28: 1093-1100.

Zeng B, Zhang XQ, Lan Y and Yang WY (2008). Evaluation of genetic diversity and relationships in orchardgrass (Dactylis glomerata L.) germplasm based on SRAP markers. Can. J. Plant Sci. 88: 53-60. 